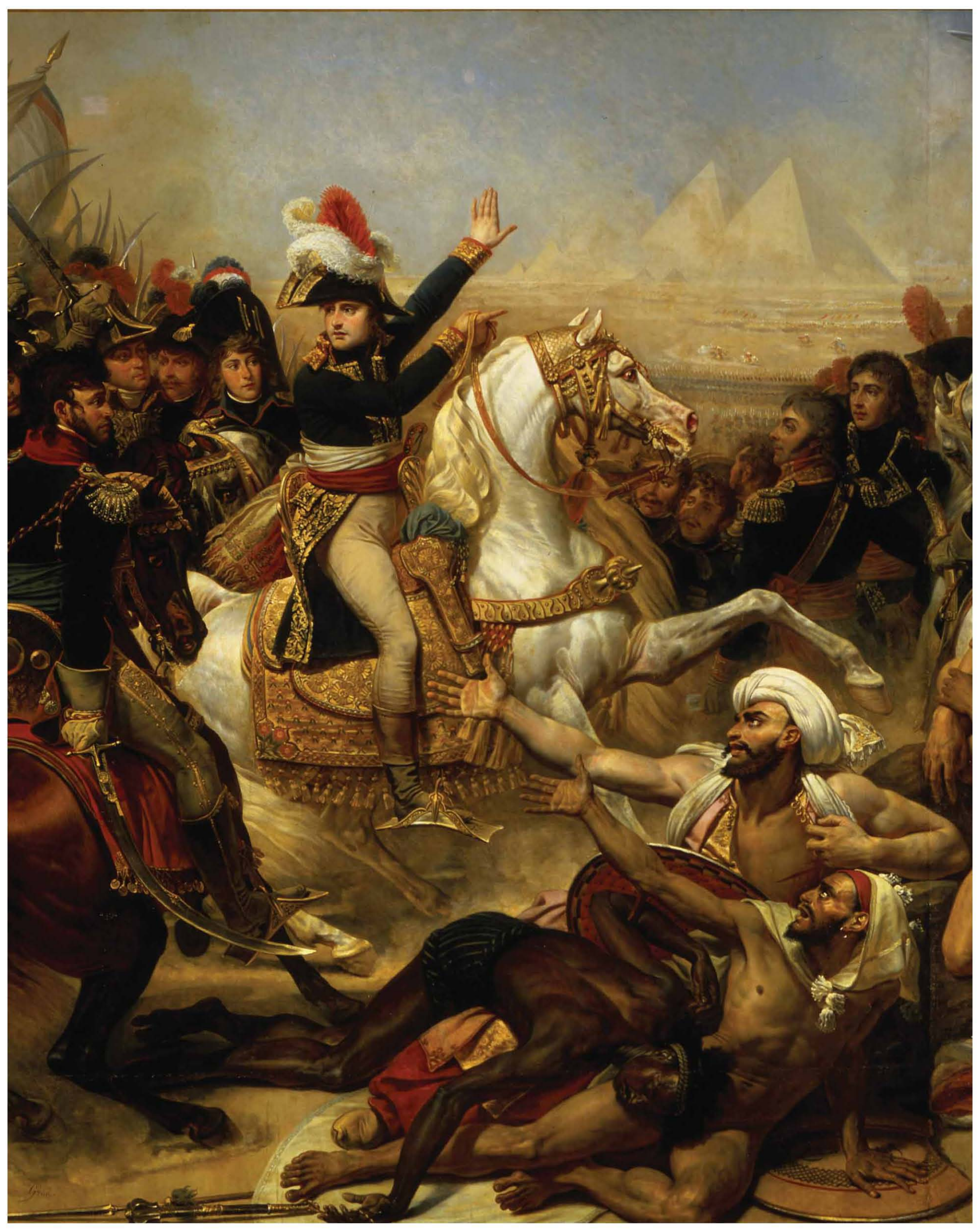




\section{Egyptian Stars under Paris Skies}

by Jed Z. Buchwald

Left: Napoleon urges on his troops at the Battle of the Pyramids. (Detail from Antoine-Jean Gros,

Bonaparte haranguant

l'armée avant la bataille

des Pyramides, le 21 juillet

1798.) But, while he won

the battle, he lost the war.

Napoleon left Egypt in

1799; his deputy was assassinated (below: Victor

Adam, Assassination of

Kléber by a fanatic, 14

June (800); and the English defeated the French in 1801 .

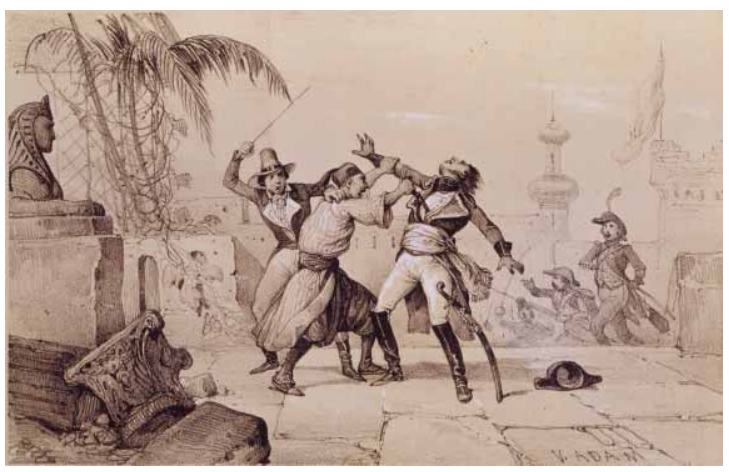

One evening in early July of 1822 a group gathered for dinner at the home of the leading figure in French science, the Marquis de Laplace, outside Paris. The guests included five of the most distinguished physicists and chemists of the day: Jean-Baptiste Biot, famed for his experimental work in optics and electricity; François Arago, rapidly becoming an influential administrator of science, the editor of an important journal, and himself a reasonably accomplished experimenter in optics; Joseph Fourier, who had developed the series representation now termed Fourier analysis and whose controversial theory of thermal diffusion had already been widely discussed; the influential chemist Claude Berthollet; and John Dalton, the English protagonist of the atom.

The previous several years had seen remarkable developments in French science, including fundamental discoveries in electricity, magnetism, heat, and optics. Most of the dinner guests had participated in these events, often on opposing sides. Biot and Arago were scarcely on speaking terms, Fourier's mathematics and his heat theory were not well thought of by Biot and Laplace, and Berthollet had little sympathy for chemical atomism. Yet the evening's conversation had nothing to do with physics, chemistry, or mathematics. Instead, the guests discussed the arrival in Paris of a zodiac from a ceiling in the Egyptian temple of Dendera, far up the Nile. Sawn and exploded out of its site by a French archaeological vandal named Claude Lelorrain, the Dendera zodiac roused Parisian salons and institutes to such an extent that for several months it displaced all other topics, attracted crowds of curious admirers, and was soon bought by King Louis XVIII for an immense sum. This was not the first time that Dendera had ignited discussion. On his return from Napoleon's colonial expedition to Egypt in 1799, the artist Vivant Denon had made available his sketch of what certainly looked like a zodiac. In short order articles appeared concerning the age of what many took to be a relic of antique Egyptian skies. For if the zodiac were literally an image of the heavens, then astronomy might be used to establish its date of production. Since hieroglyphs were to remain unreadable for another two decades, Dendera offered the tantalizing possibility of establishing Egyptian chronology on the basis of something beyond the few Greek and Latin texts that had been carefully studied by Renaissance humanists. Though some of these texts contained words that could be interpreted astronomically, a great deal of speculation and argument was needed. Several French scientists of the day were convinced that the Dendera ceiling was much more reliable than words. Words, filtered through the sieves of human culture and history, were thought by an early cadré of French savants known as Idéologueswho were concerned with social systems - to be imperfect reflections of external reality. Images seemed to be different, more trustworthy, because they were considered to connect directly to original sensations stimulated by the natural world. Here lay the seeds of a growing mismatch between historical and scientific sensibilities, at least in 19th-century France, and likely elsewhere as well.

The French astronomer and head of the Paris Bureau of Longitude, Jérome de Lalande, heard about Denon's as yet unpublished sketch in 1800 . Reports that he read seemed to indicate that the circular zodiac was at least 4,000 years old. Furthermore, a second star ceiling discovered at Esneh seemed to be older still, dating perhaps to 7,000 years before the present era. If Esneh were that old, Lalande concluded, then a claim made by one 


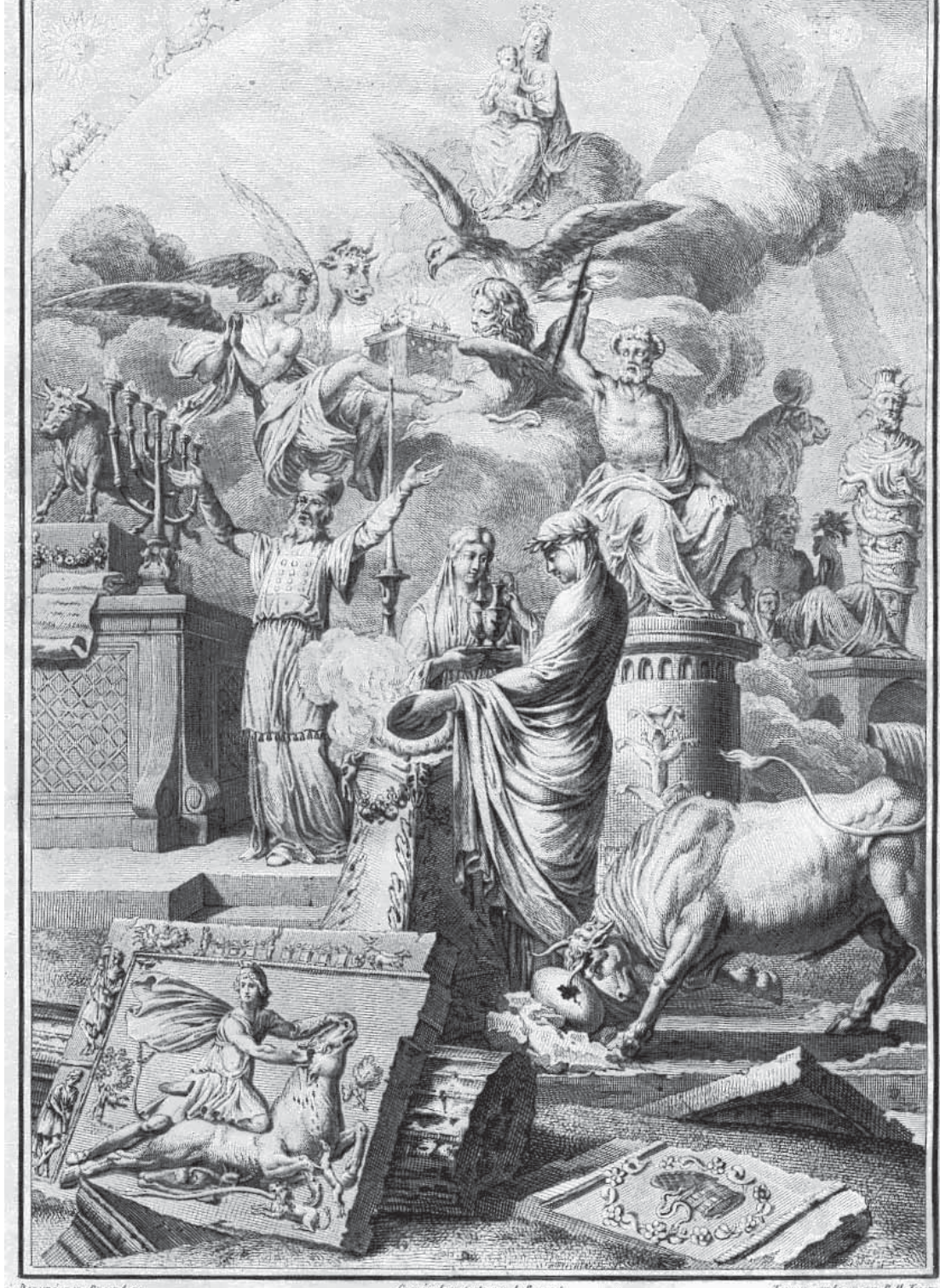

Charles Dupuis just before the French Revolution concerning the origins of religion, which interpreted myths in astronomical terms, might well be correct. Dupuis had located the birthplace of the zodiac in an Egypt older by far than any chronology based on textual arguments_-and especially on the Books of Moses-could possibly allow. (Standard biblical chronology placed the origin of all things at about 4000 B.C.E.*) According to Dupuis, the zodiac, and astronomy itself, was born near the Nile over 14,000 years ago. The Greeks, he insisted, were scientific children compared to the Egyptians, whose knowledge and wisdom underlay all of Western science and mathematics.

The details of Dupuis' argument were new, and its feverish antireligiosity breathed the atmosphere of pre-Revolutionary France, but Egypt had been considered the original source of knowledge as early as the time of Plato. Scholars in the 17 th century had provided countervailing arguments. Isaac Casaubon, for example, had demonstrated in 1614 that one group of texts - the influential Hermetic Corpus - actually dated from about 200
Charles Dupuis' Origin of

All Cults (frontispiece at

left), published in 1795 ,

traced all religions (and

myths) back to the

Egyptians' knowledge of

astronomy. Dupuis dated

Egyptian astronomy and

the zodiac at 14,000 years

earlier, about 10,000 years

before biblical chronology

set the creation of the

world.

C.E. and not, as had been claimed, from Egypt near the time of Moses. Nevertheless, Egypt and the mysteries of its hieroglyphs continued to capture the European imagination throughout the 18th century. Constantin François Chasseboeuf, who had renamed himself "Volney" in admiration for Voltaire and Voltaire's residence, Ferney, produced a widely read account of his travels to Egypt and Syria between 1783 and 1785 that fed directly into this existing fascination. In his well-known works Volney argued that history amounts to a succession of continually reemerging ancient civilizations. This vision influenced Napoleon, who conceived his invasion of Egypt in 1798 as the latest act in Volney's grand historical drama. For Napoleon expected to be greeted as a liberator by native Egyptians, descendants of a wise and graceful past, who had been subjected for centuries to the oppression of the Ottoman Turks and their Mameluke satraps.

The Napoleonic expedition was, in the end, a military debacle. Native Egyptians had little love for the Mamelukes, but neither did they greet the French invaders as liberators. Revolts and resistance to the occupation were frequent, and the French responded with great brutality. The English fleet under Admiral Nelson destroyed the French armada not long after its arrival at Alexandria, effectively isolating the French army in Egypt. Napoleon returned clandestinely to France a year later, leaving in charge General Kléber, who was assassinated nine months afterward by a Syrian who detested the presence of non-Muslims in Egypt and Syria. The French occupiers were forced to capitulate to the English by the end of August 1801.

The military failure of this first French colonial invasion of North Africa was soon overshadowed by the immense fund of knowledge concerning Egyptian antiquity that the expedition brought back (as well as by effective Napoleonic propaganda). Here, too, French beliefs concerning the 
course of history influenced attitudes toward Egyptian civilizations, past and present. Napoleon, trained as he was as a military engineer, and considering himself a natural philosopher and mathematician, had brought along on his flagship many of the most famous scientists of the dayhis savants. Napoleon's military did not get along well with the savants; neither did the soldiers exhibit much tolerance and understanding of Egyptian customs. The savants (though military men themselves) had much greater sympathy and understanding for both the fellabin, or peasants, and the literate classes, but even they expected to find a people debased, or at least mired in ignorance, by centuries of alien oppression and by adherence to what they regarded as religious superstition. Of course, the savants thought all religions to be forms of superstition, so in this respect their condescension was ecumenical. They

Egypt as it is (right) and Egypt as it was (below), in the eyes of the early-19thcentury French.
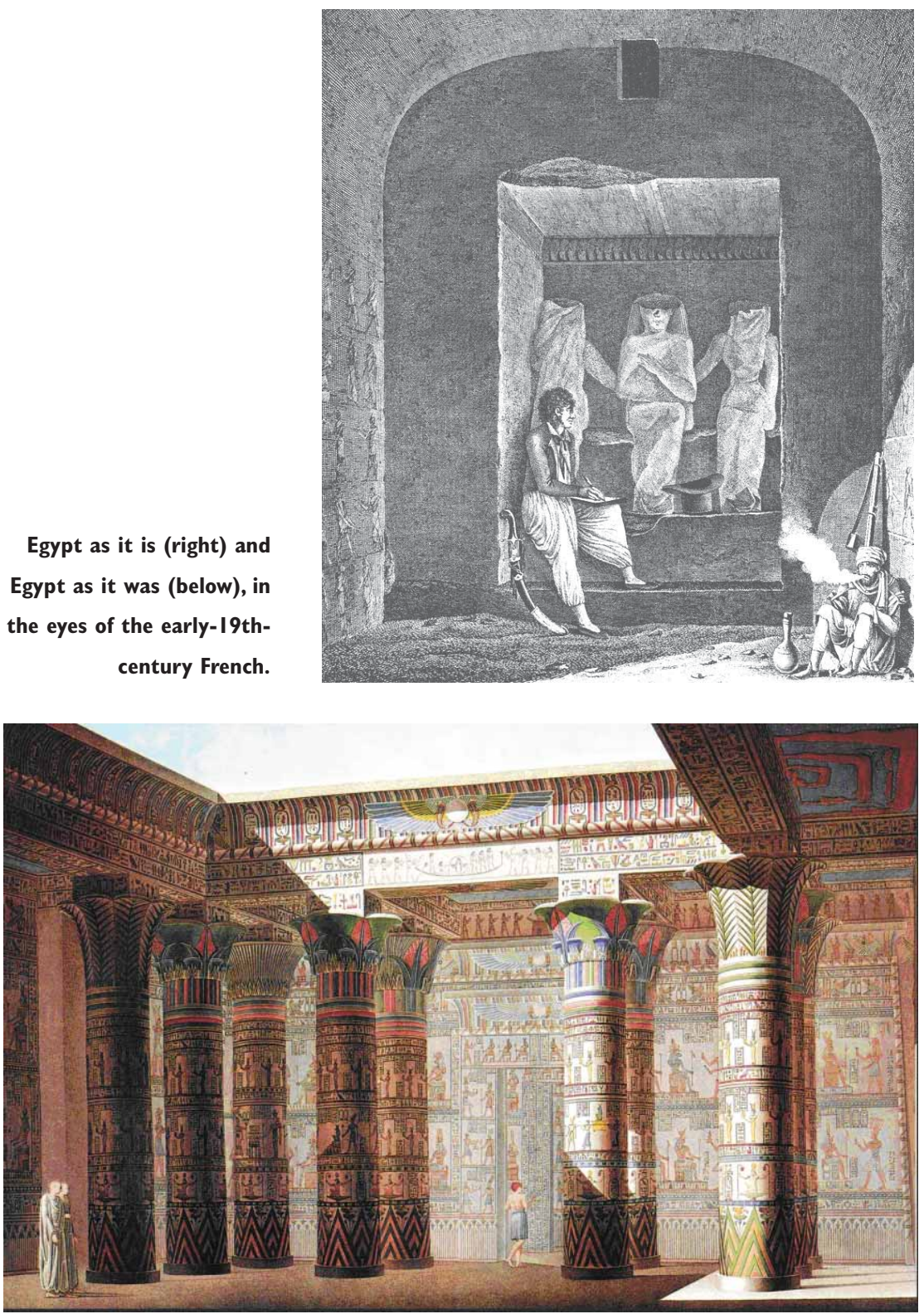

found what they had anticipated, as we can see from the iconography in the drawing (left) by one of the artists who accompanied the expedition.

Note the attentive, busy artist dressed in French jacket and Egyptian pantaloons, curved sword at his side. He stares intently at an ancient frieze of what appear to be veiled pharaonic-era women. At lower right sits the artist's Egyptian companion, intent on nothing more than his hookah. He clearly has nothing to do with the regal and mysterious image that captures the artist's attention. To see just how far Egypt had fallen from its glorious past, we need only look at one of the magnificent drawings (left, below) through which the French imagined the Egypt of the pharaohs, where we see stately Egyptian priests, dressed like Roman senators, walking with slow dignity through an imposing temple. This imagery, this contrast, together with the complex interactions of the religiously indifferent conquerors with the unhappy and uneasy Muslim populace had profound effects on subsequent French, and indeed European, views of the Muslim world-a world that was sophisticated, erudite, and elegant, though not in ways that even sympathetic Europeans of the day could easily appreciate.

Educated Egyptians reciprocated French disdain. Al-Jabarti, from Cairo, a chronicler of the invasion, had this to say of the French establishment of a Diwan, or court, to adjudicate property issues_- "In the form of this Diwan the French established a basis for malice, a foundation for godlessness, a bulwark of injustice, and a source of all manner of evil innovations." Moreover, the French Arabists who accompanied the expedition apparently had little sense of the language's character, which greatly annoyed Al-Jabarti, who deplored their "incoherent words and vulgar constructions." Not only were the French linguistic barbarians, they were disturbingly irreligious, for "they believe the world was not created, and that the heavenly bodies and the occurrences of the universe are influenced by the movement of the stars, and that nations appear and states decline, according to the nature of the conjunctions and the aspects of the moon." In Al-Jabarti's world the alternative to divine destiny was mechanical astrology, to which he thought the invading French "materialists" were addicted. We live today in the unfortunate aftermath of early colonial contacts such as these with the Near East.

Admiration, even awe, for Egypt past grew among the French in reciprocal measure to their disdain for Egypt present. The discovery of what seemed to be four ancient zodiacs fit neatly into this vision; all were rapidly assigned to millennia before (as we now know) the Greeks or even the Babylonians had developed astronomy. The zodiacs were first found by General Desaix - two at Esneh and two at Dendera - as he led his army up the Nile near Luxor. The artist Vivant Denon rapidly sketched the most interesting of the four, 

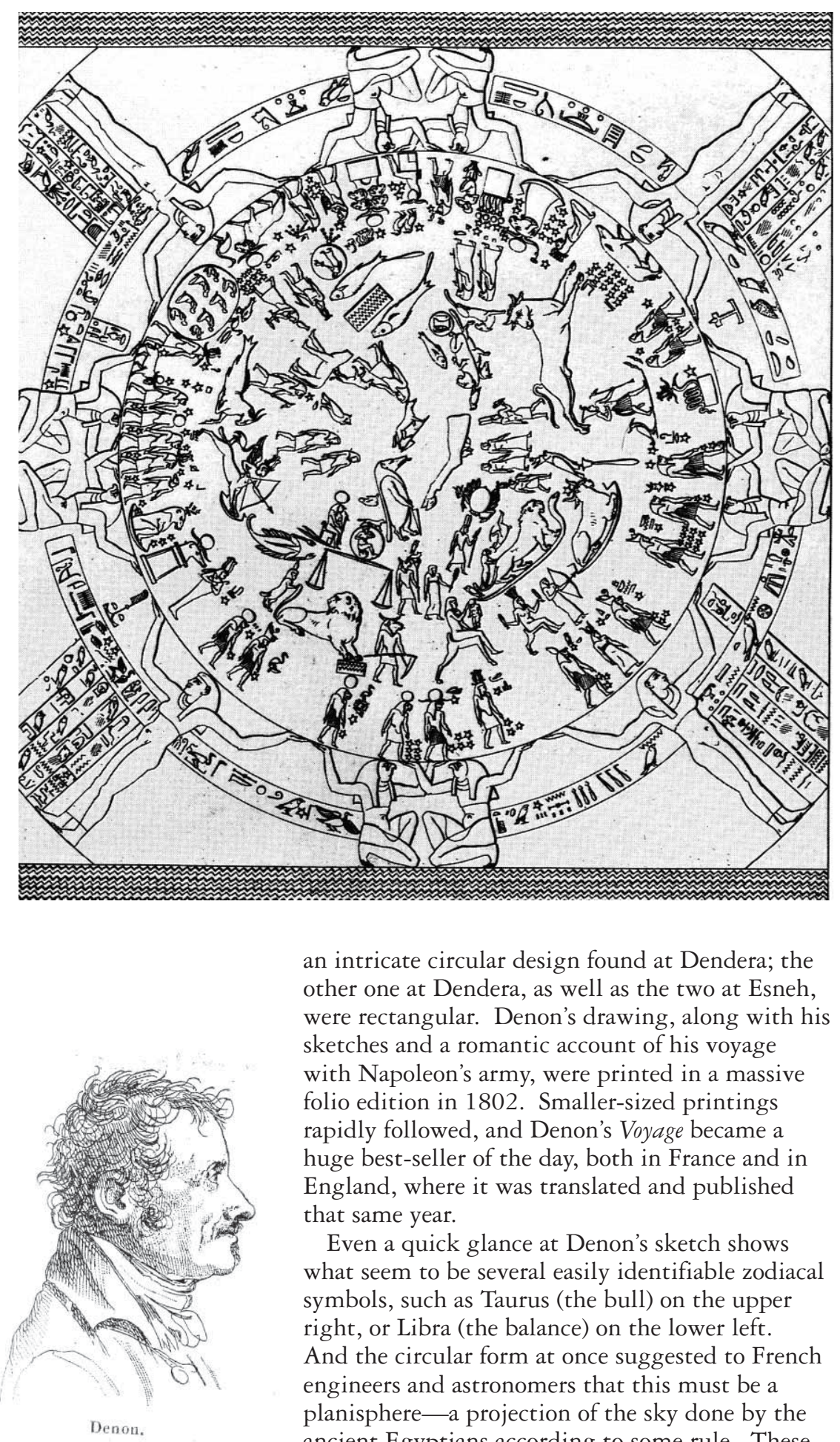

an intricate circular design found at Dendera; the other one at Dendera, as well as the two at Esneh, were rectangular. Denon's drawing, along with his sketches and a romantic account of his voyage with Napoleon's army, were printed in a massive folio edition in 1802. Smaller-sized printings rapidly followed, and Denon's Voyage became a huge best-seller of the day, both in France and in England, where it was translated and published that same year.

Even a quick glance at Denon's sketch shows what seem to be several easily identifiable zodiacal symbols, such as Taurus (the bull) on the upper right, or Libra (the balance) on the lower left. And the circular form at once suggested to French engineers and astronomers that this must be a planisphere-a projection of the sky done by the ancient Egyptians according to some rule. These, they thought, were not true cultural artifacts. Rather, the zodiacs skipped past the vagaries of human life and society to reflect nature as it truly was when they were produced. But what did they show, and when were they made?

Relying extensively on Dupuis' argument that the zodiac originated in Egypt millennia ago, and that its signs reflect the particular climatic conditions prevalent at the time, the astronomer Johann Karl Burckhardt and the engineer JeanBaptiste Coraboeuf, both in Egypt as part of the
Vivant Denon sketched the round zodiac (left) in the ceiling of the Temple of Dendera, publishing it in

1802. Contemporary astronomers and engineers believed it to be a true representation of the sky at the time the zodiac was produced.

expedition, argued that the Dendera zodiacs were produced about 2000 B.C.E., and that one of the two at Esneh might reach as far back as 6000 B.C.E.

Moreover, Burckhardt and Coraboeuf arrived at such astonishingly antique dates using the precession of the equinoxes, a phenomenon they were convinced was known to the ancient Egyptians.

The earth's axis does not remain parallel to itself as the planet revolves about the sun; it executes a very slow conical motion about the earth's center, called precession. At the end of the 18th century the period for precession was known to be about 25,748 years (as compared to the 36,000 years given by the Alexandrian astronomer Ptolemy in the 2 nd century C.E.). Precession affects chronology in the following way: The plane of the earth's orbit cuts a great circle on the apparent sphere of the stars called the ecliptic, along which lie the zodiacal constellations. Since the sun appears to move along the ecliptic, during the course of the year it travels bit by bit through the zodiac. Twice a year the sun lies at the intersection of the ecliptic with the projection of the earth's equator onto the stellar sphere, and at these equinoctial points the hours of day and night are equal. The two points that lie on the ecliptic at $90^{\circ}$ to the equinoxes are the solstices, and here the hours of daylight are longest (at the summer solstice) or shortest (at the winter solstice). Because of precession, the position of the sun at the equinoxes and the solstices with respect to the zodiacal constellations changes over time. For example, in about 2000 B.C.E. the spring equinox lay in Libra, and the summer solstice in Leo; whereas by 1800 C.E., the spring equinox had moved to Virgo and the summer solstice to Cancer.

One of the rectangular zodiacs at Esneh had the sign for Virgo at its left end, while the comparable one at Dendera had Leo in the same position. The circular zodiac, Burckhardt and Coraboeuf argued, seemed to spiral in from Leo (a doubtful claim, given Denon's sketch-or even the original). If 
the first sign in the rectangular zodiacs marked the summer solstice then, precessing backwards in time until the solstice occurred in Leo, the Dendera zodiacs had been produced no later than 2000 B.C.E. Taking the rectangular Esneh zodiac to begin with Virgo, it would date to about 5000 B.C.E. Since even the Dendera representations must have been preceded by at least several centuries of development, it seemed to LEOE of evidence. Why assume that the sequence

During the course

of a year, the sun appears to move through the zodiac along the plane of the ecliptic. But because

of precession of the earth's axis (over many thousands of years), the position of the sun changes over time with respect to an individual constellation at a given point of the year, say the summer solstice (yellow dots). Locating the summer solstice in Virgo in 5000 B.C.E. provided "evidence" of the ancient age of the Egyptian zodiacs.

The dour Dionysius Petavius (right) dated Noah's flood at 2300 B.C.E. in the rectangular zodiac begins with the summer solstice? The solstice is, after all, extraordinarily hard to pin-point by observation, and in any case it was known from Greek texts that the Egyptians were particularly concerned with the heliacal rising of the brightest star in the sky, Sirius - that is, with the night when Sirius first appears, just before dawn. In Egyptian prehistory this event certainly preceded the annual flooding of the Nile, which was of obvious agricultural importance. Would not precession have moved Sirius along with the zodiacal stars, eventually decoupling its heliacal rising from the solstice, and so from the annual inundation? We know today that the inundation occurs after the June beginning of the rainy season in Ethiopia, where the Blue Nile rises. And yet Sirius' heliacal rising remained a central marker of the year throughout Egyptian history.

These kinds of objections, which in various forms appeared over the years, are essentially technical. They presume that the zodiacs are reasonably accurate drawings of the heavens as the Egyptians saw them at the time of their creation. For the next two decades many participants in the intense controversies that soon erupted did presume just that. This meant that objectors to the several dating schemes that emerged had either to offer technical counterpoints, or to propose new schemes of their own. Both types of critiques occurred. And, we shall see, the controversy changed in nature over the years with the social and political circumstances of Napoleonic and then Restoration France.

Burckhardt and Coraboeuf's dating became known from remarks printed in a volume describing the pyramids at Ghiza by another member of the Napoleonic expedition named Grobert. Publicized a few years later by the astronomer and ardent atheist Lalande, who nevertheless disagreed with their claims, these early remarks soon produced a powerfully antagonistic reaction. For even the dating of the circular zodiac to no later than 2000 B.C.E. came perilously close to the period assigned to Noah's flood, namely about 2300 B.C.E., as established by such 17 th-century chronologers as Dionysius Petavius or Bishop Usher. As one ardent objector named Dalmas put it a number of years later, "Since everything on earth bears witness to a catastrophe similar to the deluge, and since even our incredulous ones believe in it, or at least can't deny it, [to accept their views would mean] to think that, from the moment the deluge ceased, men worked anew to reproduce their settlements on the earth ... and it seems that a period of 17 to 20 thousand years would be required between us and the delugethat's where this philosophy takes us."

Mosaic chronology, along with religious sentiment and belief, had long been subject to derision by French philosophes. On a visit to Paris in 1774 the English natural philosopher Joseph Priestley, who himself held decidedly unusual theological views, remarked that he found "all the philosophical persons to whom I was introduced at Paris, unbelievers in Christianity, and even professed Atheists. As I chose on all occasions to appear as a Christian, I was told by some of them, that I was the only person they had ever met with, of whose understanding they had any opinion, who professed to believe in Christianity." Dupuis' work, which appeared in book form 20 years later, shortly after the end of the Revolutionary Terror, had grown in fertile ground.

But circumstances had changed considerably by 1802. In July 1801 Napoleon, as First Consul, and Pope Pius VII agreed to reestablish the

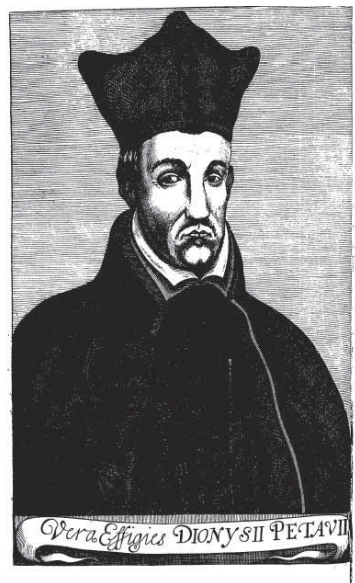




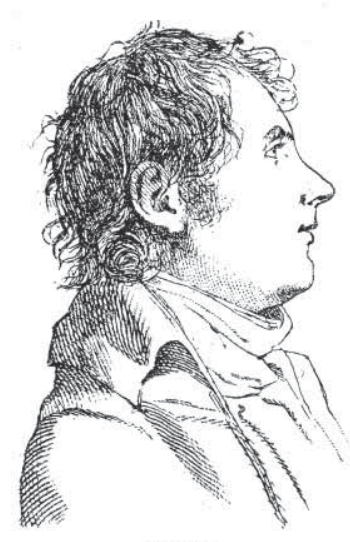

Fourier.

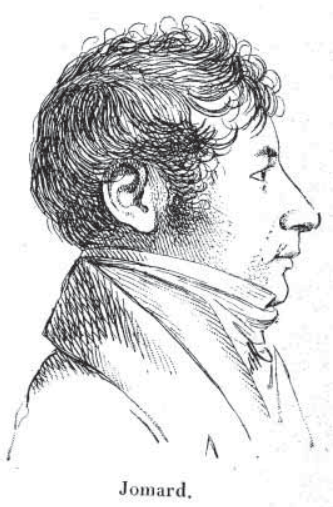

Catholic Church in France as the religion "of the great majority," though not of the state itself. The agreement contained the provision that worship must conform "to such police regulations as the government shall consider necessary to public tranquility." Napoleon, though himself completely irreligious, wished to avert any faithinspired insurrections, and he used police power not only to control public worship but also to manage what the press might say about religion. Newspapers were not to print articles that were either critical of religion, or, conversely, that seemed to elevate religious claims above those of the state. Enforced by Napoleon's chief of police, Joseph Fouché, press censorship rapidly dampened critical discussions that had any kind of political tinge.

At this time the zodiac debates were just beginning. Scarcely a week before the Concordat was announced, a priest in Rome named Domenico Testa, acting with the full approval of the Vatican, had produced a long screed on Dendera that vigorously refuted the claims for its antiquity. Also in Rome, Ennio Quirino Visconti, an unsuccessful rival of Vivant Denon's for directorship of the new Musée Napoleon, further attacked Dendera's antiquity on the grounds that the temple showed every sign of having been constructed in GrecoRoman times. Dupuis himself entered the fray in 1806 , but by then censorship had taken hold, and he was careful to distance himself from discussions of chronology; he would instead write only about the "nature of the monument," despite his own long-standing belief in the Egyptian origin and antiquity of the constellations. Fouché's secret police were ubiquitous and feared, and Napoleon was by now more than First Consul; he had crowned himself Emperor in 1804.

By 1809 the writer Chateaubriand, who dedicated his Génie du Christianisme to the dictator Napoleon, had begun infecting a generation with Romantic religiosity and hatred of republicanism. His writings, and those of others like him, cast a pall over skepticism, and certainly over critical historical discussion. That year the first volumes of the magnificently illustrated Description de l'Egypte appeared. With an introduction by Joseph Fourier-mathematician, member of the expedition, and now Napoleon's prefect in Isère-the Description revived the Dendera affair. Moreover, the Description contained a detailed and reputedly accurate drawing of the Dendera zodiac by the French engineers. Thoroughly conscious of the regime's aversion to anything that might offend belief and revive political tensions, Fourier and Edme Jomard only insinuated and hinted at their true views throughout the Description. Fourier had convinced himself that the zodiac dated to about 2500 B.C.E., while the engineer Jomard, who had also investigated the metrics of the pyramids, opted for many millennia before that, no doubt following Dupuis' original chronology for the constellations. This politically careful dance did not fool anyone, though it was enough to avoid Fouchés censors, and over time many readers discerned Jomard's and Fourier's opinions.

Arguments for Egyptian antiquity were cast further into the scholarly wilderness by the appearance in 1812 of Georges Cuvier's masterful account of the origins of fossils, and in particular its discussion of the ages of the earth. Cuvier, who had crafted the science of comparative anatomy, argued for the earth's having undergone a series of revolutions or catastrophes, with each one having propelled the globe into a new geological regime. The most recent, he asserted, was the Biblical Deluge, so powerful and all-encompassing that no evidence of antediluvian humanity could possibly have remained. As to chronology, Cuvier was circumspect in general, but not with regard to human history. Surveying with equal distance the records of the Hebrews, Chinese, and Indians, Cuvier concluded that all supported the existence of a massive flood at most several thousand years ago. As for the Dendera zodiac, which he mentioned, claims for its greater antiquity were dismissed. Cuvier, who had also mastered the niceties of patronage, which had led him to a position of power by the beginning of the Empire, no doubt also understood the need for circumspection in matters chronological.

Then, in 1814, after increasingly severe military defeats and social upheaval, Napoleon abdicated and was exiled to Elba. Louis XVIII, brother of the decapitated king, returned with his entourage of embittered émigrés, who found their estates sold, their privileges eliminated, and, perhaps worst of all, their claims to social preeminence usurped by a new class of nobles created by Napoleon. During the year of this First Restoration, Louis XVIII, though certainly no liberal by inclination, forestalled his angry relatives and aristocrats, attempting to create a new social consensus that would not be based on revenge. The properties that had been taken from church and aristocracy and then sold off to political functionaries and Revolutionary profiteers were not to be restored, easing the fears of their now respectable owners, who had been in possession for two decades. Press censorship markedly eased, though the agile Fouché remained chief of police. But Napoleon returned from Elba in the spring of 1815 , and the restored monarchy fled in anguish and anger. After Napoleon's final defeat at Waterloo three months later the allies and the re-restored monarchy would brook no compromise, though Louis, evidently conscious of political realities, again remained less punishmentminded than his vengeful aristocrats.

Occupied Paris was infested with English, Russian, and Prussian soldiers. The English Prince Regent, in an effort to break the French spirit once and for all, proposed removing all of the artworks that had been plundered from France's conquered territories for installation in 


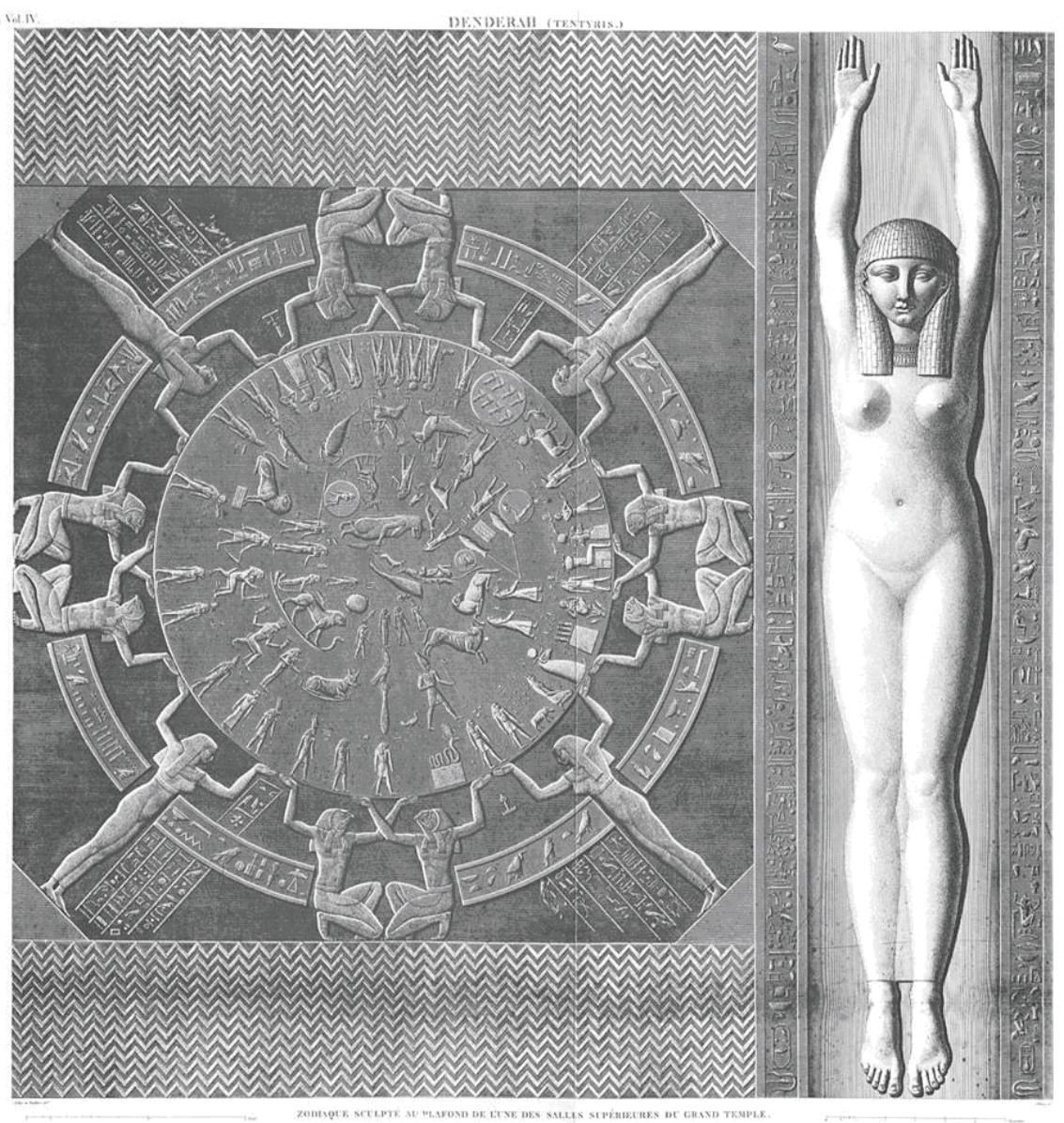

the Louvre. This, perhaps more than any single event of the occupation, deeply angered even those with Royalist sympathies. As one English visitor to the Louvre remarked, "Every Frenchman looked like a walking volcano ready to spit fire." In the event, few works of art were removed, due to clever maneuvers on the parts of Denon and others. Within a few years the Restoration government had undertaken to imitate its Napoleonic predecessor in seeking glory through the theft and purchase of artworks and antiquities.

Newspapers flourished during these years, and the press certainly remained much freer than under Napoleon-though always under suspicion - but the monarchy nevertheless attempted to infuse the nation (or at least Paris, where all important events were thought to begin and end) with a renewed religiosity. It revived the faithbased pageantry of the ancien régime, leading to mawkish spectacles in which sanctimonious aristocrats paraded solemnly through the streets of Paris with lit candles-whereas police surveys of the day show that Parisians themselves had at nearly every level of society become more irreligious than ever before. The monarchy's affinity for churchly display, and its hatred for republicanism, was further exacerbated by the dramatic assassination of the only male heir, the Duc de Berri (son of Louis XVIII's brother), at the Opéra in 1820 by an antireligious, anti-Bourbon saddler.
French engineers made this drawing of the Dendera zodiac still in place on the temple ceiling, before it was blasted out and carted off to Paris. It was published in 1809 in the Description de l'Egypte, complete with a goddess and panels of hieroglyphs that did not appear in

Denon's sketch-nor,

ultimately, in the Louvre (see page 29).

Restoration Paris had its salons, where the real work of politics and social construction occurred. There were of course Royalist salons, but there were Napoleonic ones as well. Vivant Denon, for example, maintained a sort of shrine to the exiled emperor in his, surrounded by relics of the Egypt expedition, among other plundered objects. The most famous and active were the salons of the Duchesse de Duras, Madame de Montcalm, the Princesse de Vaudrémont, the Maréchal Suchet, the painter Baron Gérard (frequented by Cuvier, among other savants), and the Duchesse de Broglie. Here elegance mingled with politics as words flew back and forth over the major issues of the day.

In the midst of this febrile mixture of religiosity, politics, and social instability the Dendera zodiac made its physical appearance in Paris. The monarchy was interested in prestigious antiquities and works of art, and by the early 1820s a revived sense of rivalry with England coursed through French veins, especially where Egypt was concerned. Mehmet Ali, an Albanian originally in the employ of the Turks, had by this time gained full control of the country, and he cleverly played off the French and the British against one another in his efforts at modernization. Not overly concerned with antiquities himself, in fact often content to despoil ancient temples for their limestone, Ali would issue firmans, or permits, to foreigners for digging and even removal of relics. A man with an avid desire for the competitive (and potentially lucrative) collecting of Egyptian antiquities by the name of Sébastien-Louis Saulnier decided to obtain the Dendera "planisphere” for France. Saulnier had been Napoleon's police commissioner in Lyon as well as his prefect in both Tern-et-Garonne and the Aude. Thrown out of any official capacity during the Restoration, Saulnier occupied himself with literary and scientific matters, and became publisher of two influential periodicals.

How lucky, Saulnier remarked, that the French 
To remove the zodiac,

Lelorrain sawed,

pulled, and eventually

used gunpowder to

explode the ceiling out

of the temple. army under Napoleon had not taken down the Dendera zodiac, for if they had "it would certainly have fallen into the hands of the English, like the Rosetta inscription" (we will shortly return to the purloined Rosetta stone). To realize his dream of possession, the patriotic Saulnier commissioned a master mason of his acquaintance named Jean Baptiste Lelorrain to extract the monument from its home. Special saws, jacks, and large scissors were constructed, and Lelorrain left for Alexandria early in October 1820.

Lelorrain's adventures in Egypt have a certain romantic air about them, if archaeological vandalism can be called romantic. To remove the zodiac, Lelorrain sawed, pulled, and eventually used gunpowder to explode the ceiling out of the temple. At the time this struck several scholars, such as Jomard and the young Jean-François Champollion, as unconscionable. Today it would be both scientifically reprehensible and a likely violation of international law. Yet Egypt had long been treated by Europeans as a quarry for antiquities; many had been brought to Italy under the Roman Empire. In the 19th century Britain, France, and eventually Germany competed with one another on many fronts, not least in the purloining of antiquities. National pride, European disdain for native inhabitants (nicely honed by centuries of colonial experience elsewhere), and pure avarice brought many Egyptian artifacts to London, Paris, and Berlin. The Dendera zodiac, together with obelisks - such as the one visible today in the Place de la Concorde-were among the first. Many justified the removals by arguing that the artifacts would simply have decayed or been destroyed in Egypt, which is not altogether true, since by the 1820s Egyptians had become increasingly aware of the remote past and were seeking to establish their own museums.

Lelorrain and his loot arrived at Marseilles on September 9, 1821. After quarantine (to avoid the very real possibility of plague), the zodiac was offloaded on November 27. Almost at once "a stranger" offered to buy it for a "considerable sum." The patriotic Saulnier resisted. Early in 1822 he wrote a little book intended, in part, to drum up government interest. After discussions over where to put it, the zodiac went temporarily to the Louvre, where it excited tremendous public interest. Salons bubbled with talk about the Egyptian stars, scholars renewed their interest, religious unease reemerged, and a comedy soon appeared in a Parisian playhouse. "Paris has a zodiac from Dendera," a line from the comedy went, "so Dendera should have a zodiac from Paris." Dendera did one day have its zodiac from Paris, but not of Paris skies - a copy of its own ceiling eventually filled Lelorrain's vacant space. Public pressure led Louis XVIII to pay Saulnier the unprecedented sum of 150,000 francs for the zodiac, which was installed in the Royal Library. A good dinner in Paris at this time cost about 5 francs, so this was a huge amount, though Saulnier claimed that he had been offered more by the unnamed stranger. In 1919 the zodiac moved to the Egyptian collections of the Louvre, where it can still be seen.

Comparing the ceiling in the Louvre (opposite page) to the drawing in the Description on the previous page, we see that Lelorrain's sawn and exploded ceiling misses the goddess with outstretched arms, as well as the panels to her left and right that are filled with hieroglyphs. If we look closely at the lower left panel by her foot, we can see a hieroglyph drawn within an oval surround, called by the French soldiers a "cartouche" for its resemblance to a cartridge case. Since these panels were left behind at Dendera, and since Denon himself had not drawn them, anyone interested in the hieroglyphs had to rely entirely on the Description's print.

But the hieroglyphs could not be read, or they couldn't be until the summer after the zodiac's arrival-the summer of that diner chez Laplace where the zodiac dominated conversation. In fact, Egyptian hieroglyphs had been under intense investigation by an ardent young protégé of Fourier, Jean-François Champollion, a talented republican pamphleteer and superb linguist who was convinced that hieroglyphs could be understood only by someone who had knowledge of life as it was lived in ancient Egypt. These mute symbols, he was certain, would speak only if they were treated neither as cryptographic codes nor as mystical talismans. On September 22 Champollion finished a letter to Bon-Joseph Dacier, the permanent secretary of the Académie des Inscriptions et Belles Lettres, where philology, linguistics, and antiquity increasingly mixed and merged with one another. That famous missive explained the essential principles underlying hieroglyphs - that they are fundamentally phonetic, with ideograms used as well, some of the ideograms functioning as what Champollion called "determinatives," or unvoiced 


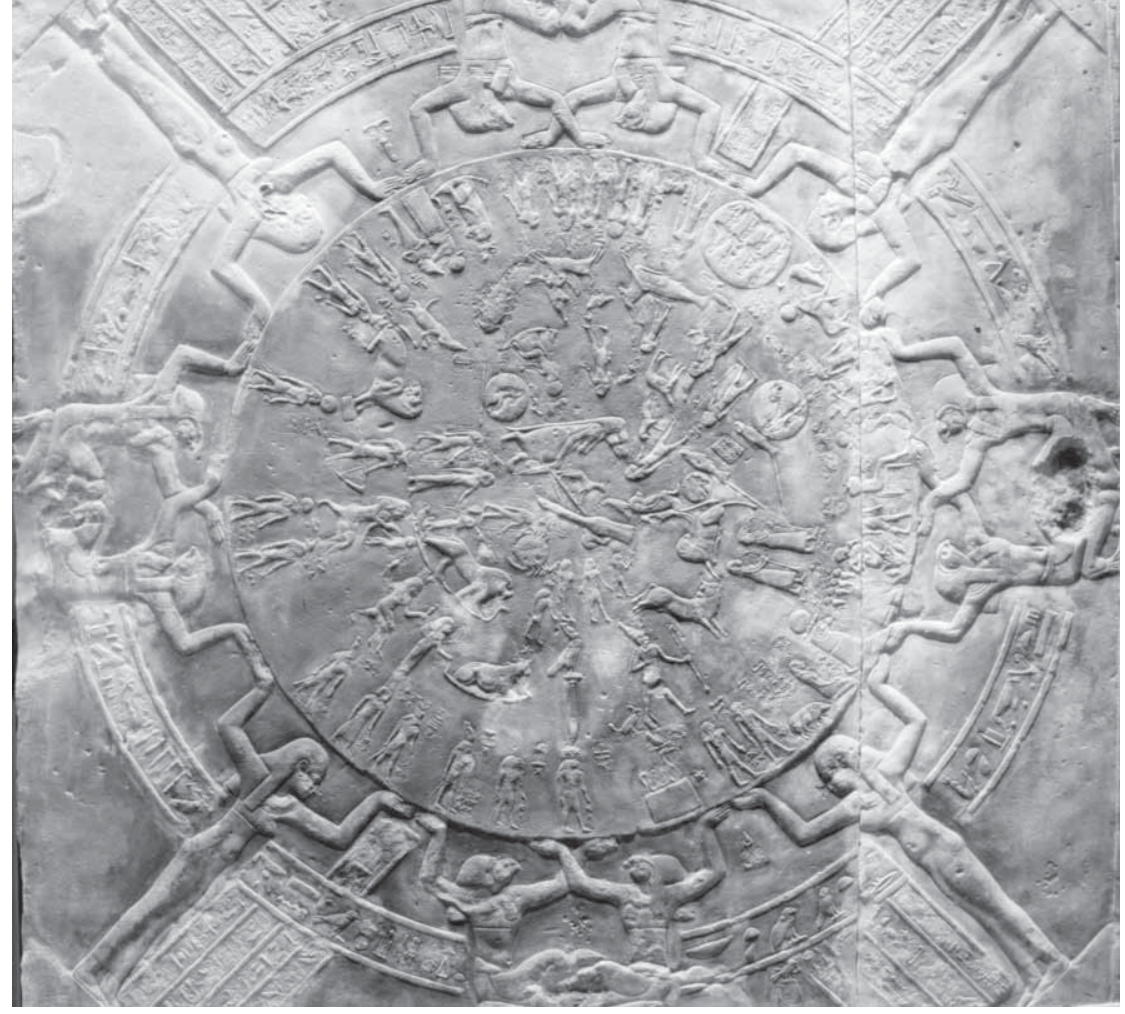

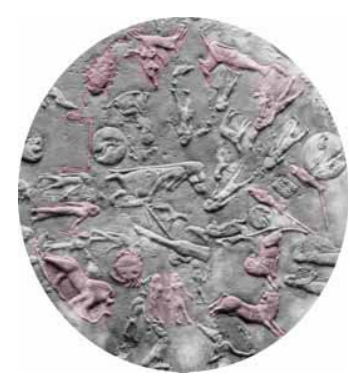

The actual Dendera zodiac, sans the surrounding depictions shown in the

Descriptions de l'Egypte on

page 27 , has been

exhibited in the Louvre since 1919. The lower

image indicates the zodiac

figures in red. signs, which specify what the text is about. Determinatives provided an essential clue to decipherment, and they were what everyone else had missed.

Champollion's was not the only attempt at the time to read the mysterious symbols. The English polymath Thomas Young had also tried his hand. Young approached hieroglyphs almost as though they were a mathematical problem, an issue of cryptographic understanding, and not as a script that was bound to ancient Egyptian ways of thinking. He had however made progress and was the first to suggest in writing that the symbols were essentially phonetic. Both Young's and Champollion's work depended upon their use of the Rosetta stone, which contained the same text in formal hieroglyphs, in the popular Demotic (or what Young called "Encorial")_ _ a late Egyptian script — and in Greek. Discovered by the French early in their expedition, the stone was taken from them (and from Egypt) by the British, when the French were forced to surrender a few years later. As it happens, not only was Young in Paris in the fall of 1822 , but he also attended the very meeting of the Académie des Inscriptions at which Champollion's letter to Dacier was read. This isn't the place to discuss the complex and increasingly angry dispute between the partisans of Young and Champollion concerning the decipherment of hieroglyphs. Suffice it to say that Young at first thought of Champollion as a junior partner who was following the trail that he had mapped out. Champollion had other ideas, and bitterness soon grew between the two.

Unfortunately for Young, this was the second time within a very short period that a junior Frenchman had apparently bested him. By 1822 the wave theory of light, which Young had devel- oped and espoused two decades before, had been taken to new mathematical and empirical heights by Augustin Jean Fresnel. Though Young remained on friendly terms with Fresnel-in part because Fresnel was much more astute in handling issues of priority than was the fiery Champollion-nevertheless, to have been displaced twice by young Frenchmen, by citizens of a nation so recently and thoroughly defeated by the English, was not altogether pleasant for the foreign secretary of the Royal Society of London.

The lines of patronage, national pride, and scientific politics twisted and turned around these people. Champollion found support from François Arago, who had been Fresnel's major patron and yet a close friend of Young's. Arago later danced nimbly around the conflicts in his obituary of Young. Arago was also close friends with Fourier, whose new theory of heat conduction he strongly supported. That theory, indeed Fourier's entire approach to physics, had long been challenged by physicists associated with Laplace, among whom was Jean-Baptiste Biot. Biot and Arago disliked one another intensely, since Arago felt, with some justification, that Biot had muscled him aside a decade before in new optical discoveries that Arago had been the first to make. This had produced a vicious and very public spat between the two.

In the spring of 1822, just before Champollion's breakthrough, both Champollion and Biot published papers on the dating of the Dendera zodiac. Despite a comparatively friendly warning from Champollion, Biot, like Fourier and other physicists before him, persisted in treating the zodiac as though it were a direct image of nature, untouched by human understanding. He identified what he took to be certain star patterns in it, applied precession, and arrived at a date of about 800 B.C.E. Champollion, now deep into his work on hieroglyphs and approaching the moment of full understanding, warned Biot that the whole business was suspect, but Biot persisted and went into print with his own astronomical dating scheme.

In a first irony, and this story has many, Biot later criticized Fourier for an incorrect application of astronomy to the zodiac. This brings us back to our beginning, to the claims of Burckhardt and Coraboeuf. Recall that they had associated the zodiacs' dates of production with the positions of the summer solstice among the constellations, which entailed that, despite precession, Sirius and the solstice must remain about the same distance in time from one another during most of Egyptian history. Indeed they do, though it's doubtful that Burckhardt and Coraboeuf had thought it through. Because of Sirius' position, and the latitudes at which the Egyptians observed the sky, both Sirius' heliacal rising and the summer solstice remained nearly the same number of days apart throughout Egyptian history even though the 


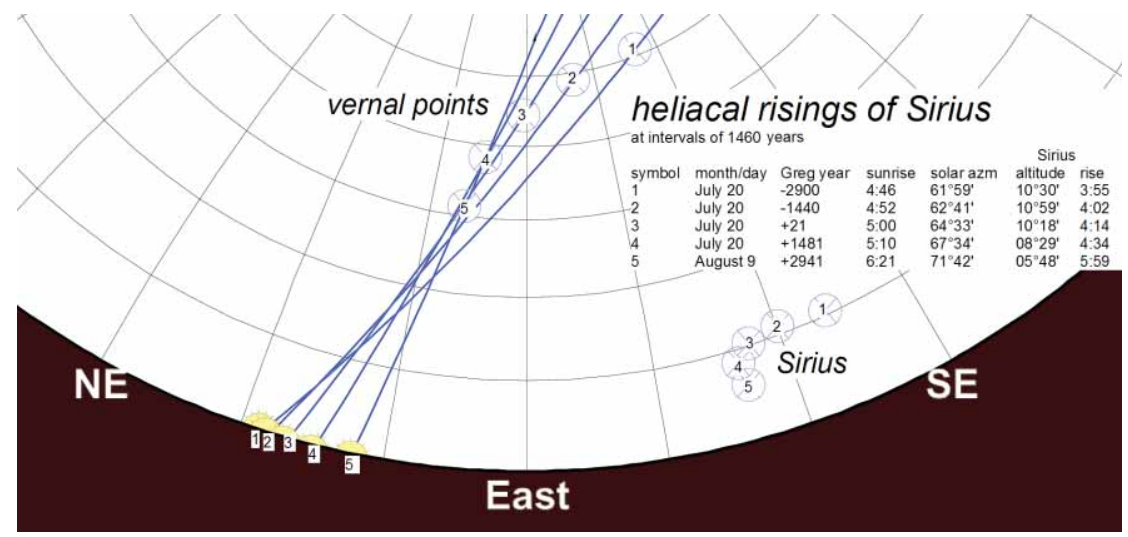

The rising of Sirius, the

brightest star in the heavens and important to Egyptians as the signal for the annual flooding of the Nile, was assumed by the French physicists to move with relation to the sun as do the constellations of the zodiac. It does not, however, as we see here.

The curved line dividing

the lit from the dark

regions represents the horizon near Dendera. The

blue lines show the

locations of the ecliptic with respect to the horizon at five helical risings separated by hundreds of years. The vernal points mark the equinoxes at these times, and the circled numbers on the lower right indicate the corresponding positions of Sirius. Sirius remains about the same distance from the equinoxes-and so from the solsticesthroughout these many centuries, despite precession. zodiac moves slowly around the ecliptic. Fourier, a masterful mathematician but evidently a poor astronomer, just assumed that Sirius would behave like a zodiacal star, making his calculations inherently flawed. Biot did not hesitate to point this out.

Though Biot persisted in his dating schemes for years, Champollion had already softened the force of his calculations by quickly publishing a refutation. Biot had after all been warned. Champollion's argument seemed to be irrefutable, even though it altogether avoided any claims for the zodiac's putative astronomical significance. For Champollion saw the constellations-like hieroglyphs themselves - as an expression of Egyptian culture. The zodiac was not a planisphere, he believed (correctly, as it turned out), but an astrological chart. In what soon proved to be a major step along his route to the decipherment of hieroglyphs, Champollion conceived that the stars depicted on the Dendera ceiling referred not to the heavens themselves but to the graphic itself. They were in fact determinatives, put there to tell the reader that the graphic was about celestial events that guide human destiny. The meaning of Egypt's stars could not be uncovered through calculations done under Paris skies.

How then did Champollion date the zodiac? What told him, as he asserted, that it certainly could not have been made before the Alexandrian conquest, and that it more likely dated to the very late period of Greco-Roman domination in the 1st century B.C.E.? The clue lay not in any image on the purloined zodiac itself, but rather in the side hieroglyphs that had been depicted only in the drawing in the Description. At the lower left of the goddess, the print displays a cartouche with (phonetic) signs that Champollion could now pronounce as autocrator, which is the Greek word for dictator. What more could one ask? Dendera's Grecian-era birth now seemed to be just as solidly established as Champollion's increasingly impres- sive readings of hieroglyphs. (And the pope offered the nonreligious Champollion a cardinalship, even though he was married with three children, for having salvaged biblical chronology.)

Debate nevertheless did not end there. Some were to argue that the ceiling might have been designed or built elsewhere and only then brought to its later surrounds, which would still permit the extravagant antiquity that Jomard had insisted upon. Others, like Biot, rejected extreme age but persisted in their astronomical games since, after all, Champollion had not proven irrefutably that the stars could not have positional meaning. In fact they don't, though the locations of planetary signs in particular constellations may perhaps be telling. Thomas Young himself perceived the folly of housing observations and calculations in the alien environment of words. "The French astronomers still persist in amusing themselves" with the Dendera zodiac, he wrote with evident sarcasm from Paris in late September 1822 to his friend William Hamilton at Naples (British minister plenipotentiary to the Neapolitan court).

Throughout the decade following Champollion's decipherment Parisian newspapers, salons, journals, and institutional meetings brimmed with exchanges about zodiacs. Pamphlets appeared in profusion, scholars attacked one another, and charges of plagiarism were thrown about. Over time the issue subsided, though it continued to erupt now and then. Years later, and especially after the publication in 1859 of Darwin's Origin of Species, arguments for the youth of Egypt were occasionally bracketed with arguments against evolutionary descent, each supporting the other.

In 1828 Champollion mounted an expedition to Egypt to see the ruins for himself. The expedition arrived at Dendera in mid-November. Entering the part of the temple that had housed the circular zodiac, Champollion saw for the first time the empty space left by Lelorrain nearly a decade before. He saw something else as well. Turning to look at the surrounding hieroglyphs that had

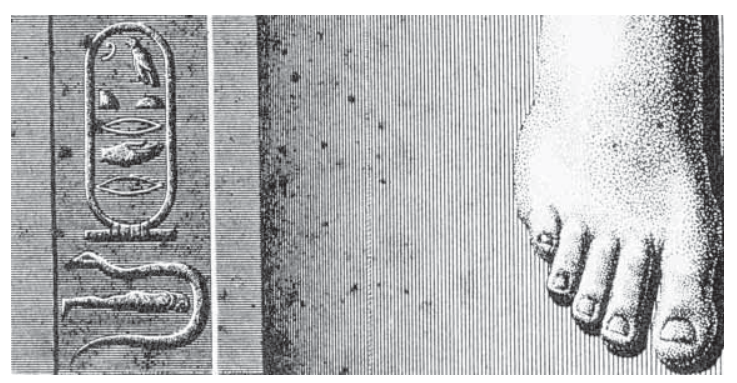

The critical cartouche near the goddess's foot in the

Descriptions drawing, whose hieroglyphics led Champollion

to the conclusion that Dendera dated from the Greco-

Roman era, turned out to be empty when Champollion visited the temple in person. 
The heated arguments that engaged so many people for more than two decades

raised the question of who was entitled to speak with authority about antiq-

uity. Was it to be the physicists and engineers, who had one view of evidence,

or philologists, linguists, and historians, who had a rather different one? not been sent to Paris, Champollion froze in dismay. Every single cartouche was empty: there were no hieroglyphs in them at all! The evidence he had so successfully, and influentially, used to date Dendera simply did not exist. Years later the reason became clear. The ceiling had been constructed during the interregnum between the death of Cleopatra's father, Ptolemy Auletes in 51 B.C.E., and the coregency officially established in 42 with Caesarion, Cleopatra's five-year-old son by Julius Caesar. Built during the interregnum, the Dendera zodiac's empty cartouches, like those of every monument constructed during that period, forever awaited royal names. In preparing the plates for publication of the Description, some enterprising draftsman had decided to fill the empty cartouches in the drawing with hieroglyphs found in other drawings. How ironic that this very absence of hieroglyphs in the cartouches now permits the monument to be dated quite precisely.

Stepping back from the colorful details of the Dendera affair, we can discern a difference among French savants that became ever sharper as the century wore on, and that remains with us today. The heated arguments that engaged so many people for more than two decades raised the question of who was entitled to speak with authority about antiquity. Was it to be physicists and engineers, who had one view of evidence, or philologists, linguists, and historians, who had a rather different one? Philologists and linguists, such as the young Champollion, understood the zodiac to be the creation of ancient Egyptian life; it spoke to the beliefs by which Egyptians at the end of the pharaonic era guided their lives. Physicists like Fourier and Biot may have disagreed with one another over which of them could better calculate the past, but both were convinced that the Dendera ceiling was an image of the Egyptian sky essentially unstained by human imagination. Even if it was imperfect, perhaps distorted by the fancies of human imagination or an ancient craftsman's lack of skill in representation, an image might nevertheless shine with evidentiary power just because it could be submitted to numbers, and in numbers alone lay truth. For words are imprecise things, and they have natural truths only as distant and distorted ancestors. Or so men like Fourier, Biot, and Jomard thought. The siren song of calculation deceived them. Al-Jabarti, the chronicler of the French invasion, might have warned them otherwise, for he knew that the sonorities and cadences of Arabic could sway the minds of men. Perhaps ancient Egyptians also beheld the world in speech. And yet Champollion, correct though he turned out to have been, and no friend of numbers, was deceived by the very absence of words he thought to be present. The mystery of Dendera was finally solved neither by numbers nor by the sounds of words, but by a new kind of historical understanding, one in which many forms of evidence-linguistic, artistic, literary, and archaeological — were together weighed and confronted with one another. There never was a Royal Road to the Egypt of the pharaohs.

\section{Jed Z. Buchwald, the Doris and Henry Dreyfuss} Professor of History, came to Caltech in 2001, after 10 years as the Dibner Professor of the History of Science and director of the Dibner Institute for the History of Science and Technology at MIT. He earned his BA in bistory (1971) from Princeton, and his MA (1973) and PbD (1974) in the history of science from Harvard. From 1974 to 1992 he was a member of the University of Toronto faculty. Buchwald's work focuses primarily on the bistory of physics from the 17th through 19 th centuries (he has written books on Hertz and electric waves and on Fresnel and wave optics) and on related issues in the philosophy of science. But he's also interested in (and teaches courses in) the social and economic history of ancient Mesopotamia and Egypt. Buchwald was a MacArthur Fellow from 1995 to 2000. 